\title{
婦人科領域覀性腫瘍摘出後の組織欠損に対して 用いた有茎皮弁術の検討
}

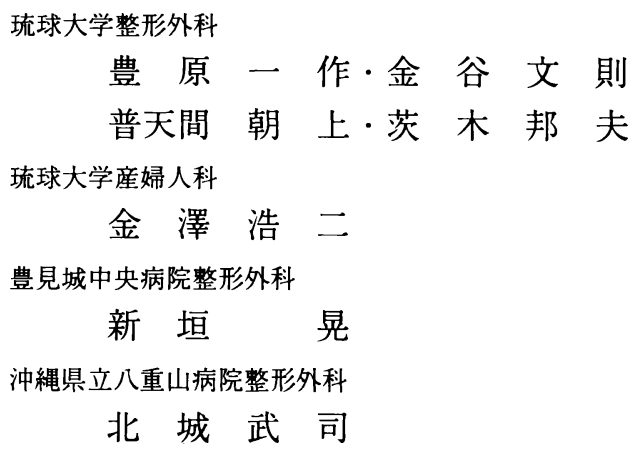

\section{Vulvovaginal Reconstruction Using Pedicle Flaps after Wide Vulvectomy and Total Pelvic Exenteration}

by

\author{
Issaku Toyohara, Fuminori Kanaya, Chojo Futenma \\ and Kunio Ibaraki \\ Department of Orthopedic Surgery, \\ School of Medicine, University of \\ the Ryukyus, Okinawa, Japan \\ Koji Kanazawa \\ Department of Obstetrics and Gynecology, \\ School of Medicine, University of \\ the Ryukyus, Okinawa, Japan \\ Akira Arakaki \\ Department of Orthopedic Surgery, \\ Tomishiro Central Hospital \\ Takeshi Kitashiro \\ Department of Orthopedic Surgery, \\ Yaeyama Prefactural Hospital
}

26 flaps were used for vulvovaginal reconstruction following radical or wide resection of malignant tumor in 15 patients. There were eleven vulvar carcinoma, two uterus carcinomas, and one vaginal carcinoma. The mean patient age was 65 years (33 85 yearold). 19 gracilis myocutaneous (M-C) flaps were used in ten patients, four posterior thigh fasciocutaneous (F-C) flaps in three patients and three local flaps in two patients. Six gracilis M-C flaps in three patients were used to supplement the dead space and vaginal reconstruction after pelvic exenteration. The other 20 flaps in twelve patients were used for vulvar reconstruction. All but one flap survived. A unilateral gracilis $\mathrm{M}-\mathrm{C}$ flap in which the skin flap was $25 \mathrm{~cm}$ in length showed partial necrosis. Two patients receiving gracilis $\mathrm{M}-\mathrm{C}$ flaps complained of discomfort during gait because of their bulk. 
One patient receiving posterior thigh F-C flap developed bursitis and required bursectomy. The other patient receiving local flaps needed debridement and closure for wound dehiscence. Gracilis M-C flaps were best suited for reconstructing both the defect after pelvic exenteration and the vagina. Posterior thigh $\mathrm{F}-\mathrm{C}$ flaps were indicated for large vulvar defect and local flaps were indicated for small defects.

Key words : gracilis flap (薄筋皮弁), posterior thigh flap (後大腿皮弁), local flap (局所 皮弁), vulvectomy（外陰部切除術）, pelvic exenteration（骨盤内臟器摘出術）

\section{はじめに}

婦人科領域悪性腫瘍の広範囲切除に伴い会陰部や骨 盤内臓器の欠損が生じる。このような症例に対して私 達は有茎（筋）皮弁による再建術を行ってきたので報 告する.

\section{対象と術式}

症例は 15 例で手術時年齢は 33 才 85 才, 平均 65 才であった. 疾患の内訳は外院癌 12 例, 子宮䅡癌 2 例, 㓐癌 1 例であった (表). 薄筋皮弁を行った症例 は 10 例 19 皮弁であり，皮弁の大きさ（幅×長さ）は 6〜9 cm $\times 14 \sim 25 \mathrm{~cm}$ であった．薄筋皮弁を用いた外 陰癌の 7 例中 6 例では両側の薄筋皮弁で外陰部を再建 し, 1 例では $8 \mathrm{~cm} \times 25 \mathrm{~cm}$ の片側の筋皮弁で再建した。 死腔補填と䐋再建を要した子宮癌 2 例と腔癌 1 例に対 しては両側の薄筋皮弁により胵を形成し薄筋腱を仙骨
前面の筋膜に縫合することにより，腹腔内臓器の下垂 の防止と同時に胠を再建した。

後大腿筋膜皮弁を行った症例は 3 例 4 皮弁で, 皮弁 の大きさは $5 \sim 10 \mathrm{~cm} \times 12 \sim 23 \mathrm{~cm}$ であった。片側の 外陰切除を行った 1 例と外陰癌の浸潤が高度で胵と膀 胱および直腸切除を行った 1 例では片側の筋膜皮弁に より，他の 1 例は両側の筋膜皮弁を用いて外陰部を再 建した。

皮唐欠損の比較的小さい例に対しては局所皮弁を行っ た. 皮弁の大きさは $6 \sim 7 \mathrm{~cm} \times 8 \sim 10 \mathrm{~cm}$ で 1 例は 片側の局所皮弁で, 1 例は両側の局所皮弁で外㓌部を 再建した。

\section{結果}

15 例 26 皮弁中 25 皮并に完全生着が得られた.

完全生着が得られなかった薄筋皮弁の 1 例は片側の 皮弁による被覆例で皮弁の遠位部に部分壊死を生じ，

表

\begin{tabular}{|c|c|c|c|c|c|c|}
\hline 皮弁 & & 年齢 & 診断 & 進行期 & 再建 & 皮弁の大きさ \\
\hline \multirow[t]{10}{*}{ 薄筋皮弁 } & 1 & 58 & 外陰癌 & stage II & 外陰部再建 & $6 \times 16$ (両側) \\
\hline & 2 & 69 & 外陰癌 & stage II & 外陰部再建 & $6 \times 18 \quad 6 \times 15$ \\
\hline & 3 & 56 & 外陰癌 & stage III & 外陰部再建 & $9 \times 23$ (両側) \\
\hline & 4 & 68 & 外陰癌 & stage III & 外陰部再建 & $7 \times 18$ (両側) \\
\hline & 5 & 72 & 外陰癌 & stage III & 外陰部再建 & $8 \times 25$ (片側) \\
\hline & 6 & 77 & 外陰癌 & stage IV & 外陰部再建 & $6 \times 15$ (両側) \\
\hline & 7 & 85 & 外陰癌 & stage IV & 外陰部再建 & $7 \times 22($ 両側 $)$ \\
\hline & 8 & 41 & 子宮癌 & stage $\Pi$ I b & 㓐再建 · 死腔補填 & $6 \times 16$ (両側) \\
\hline & 9 & 33 & 子宮癌 & stage III b & 䐋再建 · 死腔補填 & $6 \times 16$ (両側) \\
\hline & 10 & 58 & 臸癌 & stage II & 䐋再建 · 死腔補填 & $7 \times 14$ (両側) \\
\hline \multirow[t]{3}{*}{ 後大腿皮弁 } & 11 & 69 & 外陰癌 & stage 0 & 外院部再建 & $5 \times 12$ (片側) \\
\hline & 12 & 62 & 外陰癌 & stage III & 外陰部再建 & $10 \times 23($ 片側 $)$ \\
\hline & 13 & 72 & 外陰癌 & stage III & 外陰部再建 & $5 \times 15$ (両側) \\
\hline \multirow[t]{2}{*}{ 局所皮弁 } & 14 & 83 & 外陰癌 & stage II & 外陰部再建 & $6 \times 8$ (片側) \\
\hline & 15 & 64 & 外陰癌 & stage II & 外陰部再建 & $7 \times 10$ (両側 $)$ \\
\hline
\end{tabular}




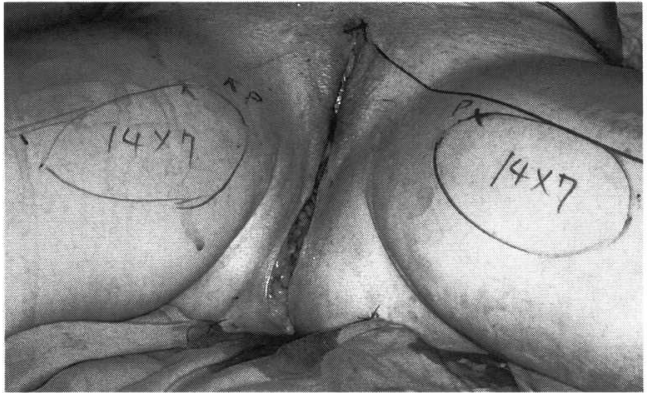

a

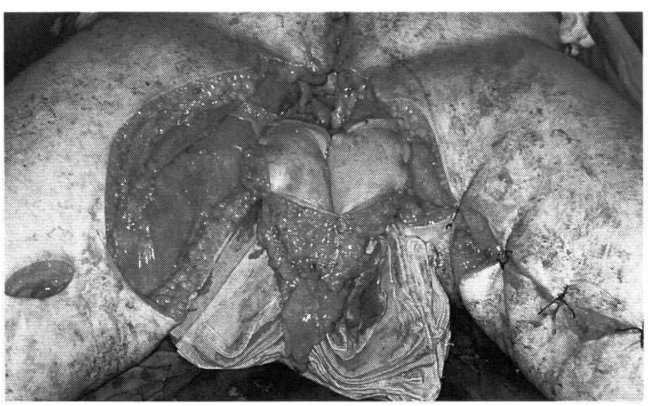

b

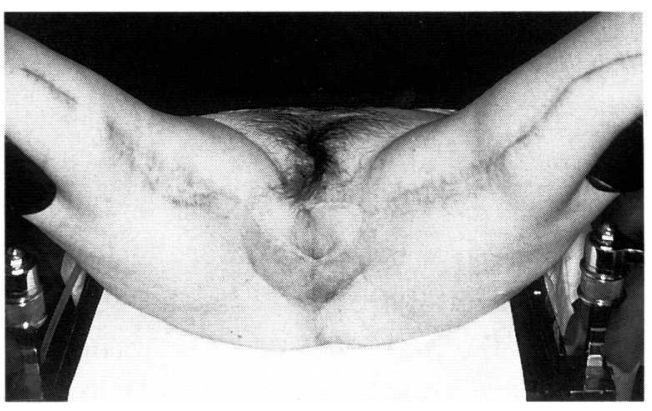

図 1 症例 1058 才 腔癌 (stage 2)

a. 骨盤内臟器郭清後, 両側 $7 \mathrm{~cm} \times 14 \mathrm{~cm}$ の薄 筋皮弁をデザインした。

b. 両側の皮弁の辺縁を綘合することにより胠 を再建し，薄筋腱の末梢側を仙骨に縫い付 けることにより死腔の補填と腹腔内臓器の 下垂を防いだ。

c. 術後 1 力月, 皮弁の状態は良好である.

対側の後大腿皮弁で閉鎖した，厚い筋皮弁による歩行 時の違和感を訴えた 2 例は 2 年以内に症状が消失した. 後大腿皮弁の 1 例では採取部の大腿後面に滑液包炎 を認めたが，滑液包切除により速やかに治癒した。

局所皮弁の 2 例 3 皮弁は全例生着が得られた。 1 皮 弁で縫合離開を認めたが, 1 カ月後デブリドマンと再

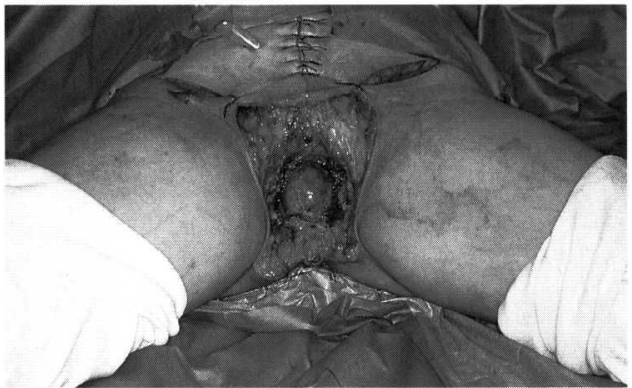

a

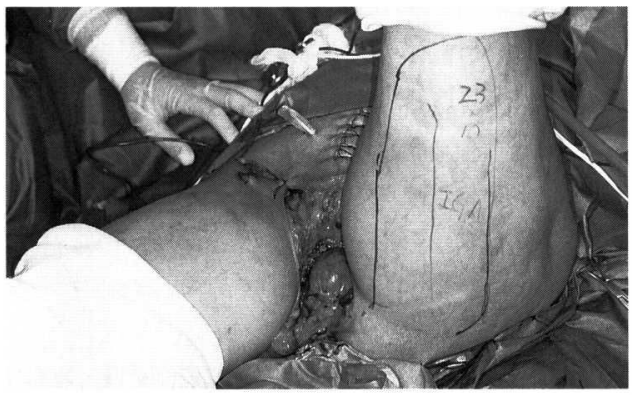

b

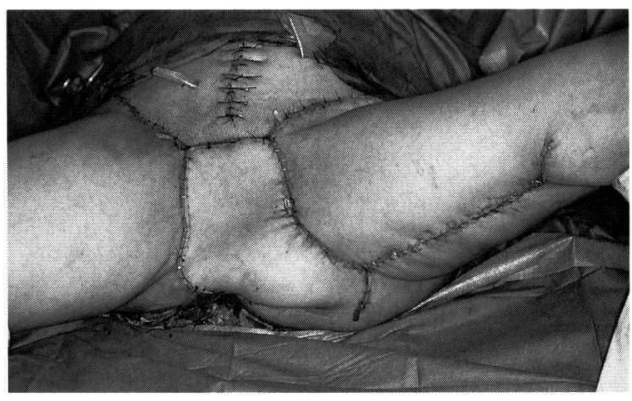

c

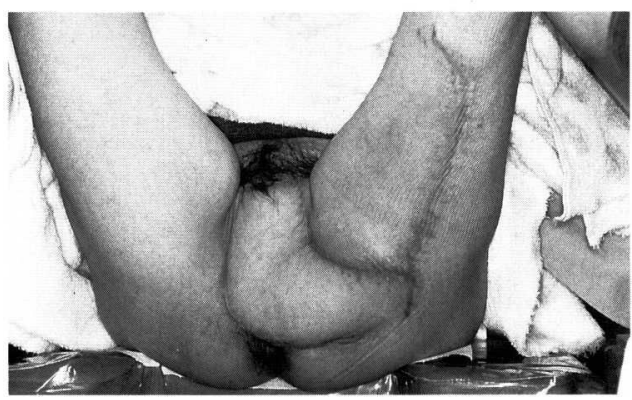

d

図 2 症例 1262 才 外陰癌 (stage 3)

a. 会陰部広範切除. 胵 - 膀胱 - 直腸切除.

b. 左側に $10 \mathrm{~cm} \times 23 \mathrm{~cm}$ の後大腿皮弁をデザインした.

c. 術直後. 後大腿皮弁で会陰部を被覆した.

d. 術後6力月，皮弁の状態は良好で患者も满足している. 
縫合を行い治癒した。

症例

症例 10.58 才, 㓐癌 stage 2 . 骨盤内臓器郭清後 の広沉な組織欠損に対して両側から $14 \mathrm{~cm} \times 7 \mathrm{~cm}$ の 薄筋皮弁を起こした，両側の皮弁で胠を再建し，薄筋 腱を仙骨前面の筋膜に綘いつけることにより死腔の補 填と腹腔内臓器の下垂を防いた。. 術後, 性交涉も可能 で患者の満足も得られた（図1）。

症例 12.62 才, 外陰癌 stage 3. 浸潤が高度であっ たため会㓌部の広範切除と膣・膀胱・直腸切除を行い, 人工肛門，回腸導管を造設した．淕，尿道口，肛門の 再建が不要であったため会除部を $23 \mathrm{~cm} \times 10 \mathrm{~cm}$ の左 側の後大腿皮弁で被覆した. 術後 6 カ月では日常生活 上も問題はなく, 患者の満足も得られた（図 2 ).

症例 15.64 才, 外陰癌 stage 2. 皮虐欠損が小さ

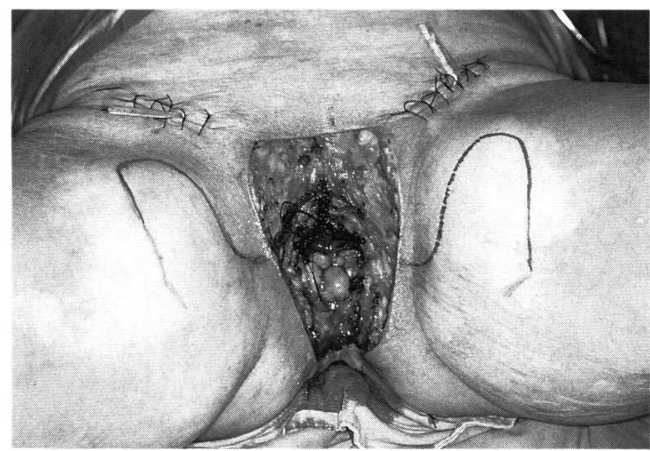

a

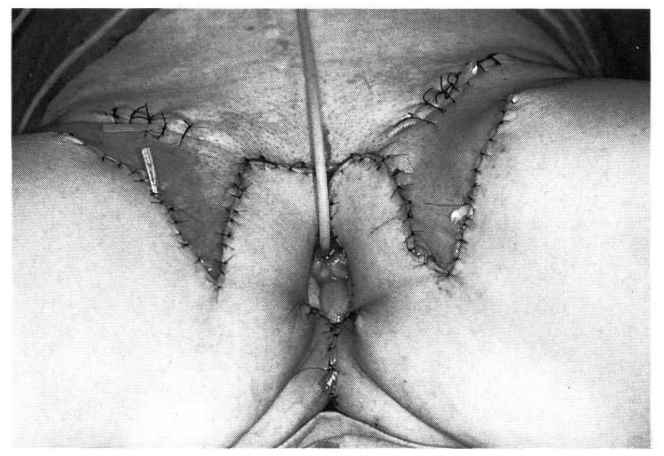

b

図 3 症例 1564 才 外陰癌 (stage 2)

a. 両側に $7 \mathrm{~cm} \times 10 \mathrm{~cm} の$ transposition flap デザインした

b. 術直後.
いため両側より $7 \mathrm{~cm} \times 10 \mathrm{~cm} の$ transposition flap を用いて外除部を被覆した（図 3)。術後, 部分的に 皮弁辺縁の縫合離開を来たしたため 1 力月後にデブリ ドマンと再縫合術を行い 2 週間後に創は閉鎖した。

考察

陰部再建に用いられる皮弁として腹直筋皮弁 ${ }^{6)}$, 薄 筋皮弁 ${ }^{13388)}$, 後大腿皮弁 ${ }^{25357)}$, 局所皮弁 ${ }^{9)}$ が挙げられ, 中でも薄筋皮弁の報告は数多〈みられる. Soper ${ }^{8)}$ は 内側大腿回旋動脈を栄養血管とする（長）薄筋皮弁 22 例 38 皮弁, および閉鎖動脈を栄養血管とする短薄 筋皮弁 24 例 45 皮弁を行い, 前者で完全壊死を 3 皮弁 に，後者で完全壊死を 4 皮弁に認めたと報告している. 薄筋皮弁は骨盤内臓器郭清後の死腔の補填や淕の再建 に有用であるが，外陰部再建に用いた場合には筋皮弁 が厚いため歩行時違和感を訴える例があり, 自験例で も 2 例にみられた. Soper ${ }^{8)}$ は短薄筋皮弁でも腔再建 が十分可能で薄筋皮弁に比べて皮弁が厚くならないこ とを強調している，薄筋皮弁の血行は大腿遠位 $1 / 3$ で は不安定であり, 自験例の片側例は皮弁が $23 \mathrm{~cm}$ と長 かったため遠位部に部分壊死を来したと思われた。

後大腿皮弁を裖創部の被覆に用いた報告? は多く, axial pattern flap で血行が安定し皮弁の合併症が 少ない点で有用である。一方, 外陰部再建に用いた報 告は少なく, Stevenson ${ }^{9)}$ は 2 例 2 皮弁を, 中西5) は 1 例 1 皮弁を報告し全例生着したと報告している. 皮弁 の大きさは遠位部は膝窩部まで, 長さは $35 \mathrm{~cm}$, 幅が $10 \mathrm{~cm}$ までと大きな皮弁が採取可能で(4)，欠損の大き な外陰再建に有用であると考える。

局所皮弁の報告例として，Davison ${ }^{2)}$ は transposition flap を 12 例 21 皮并行い, 1 例に部分壊死を 認めたと報告した。術式が簡便で手術時間が短く皮膚 欠損の小さい例には有用である.

現在私達は, 死腔補填・粍形成を要する症例には薄 筋皮弁，外㓌部再建を要する症例で欠損が大きい場合 には後大腿筋膜皮弁, 小さい場合には局所皮弁が適応 と考えている.

$$
\text { ま と め }
$$

(1)婦人科領域の悪性腫瘍摘出後の組織欠損 15 例に 対し， 26 筋皮弁術を行い 25 皮弁が生着した。

(2)合併症として薄筋皮弁では部分壊死, 後大腿筋膜 
皮弁では滑液包炎，局所皮弁では縫合離開をそれぞれ

1 皮弁に認めた。

(3)死腔補填・腔再建には薄筋皮弁, 外陰再建には後 大腿皮弁または局所皮弁が有用と考えた。

\section{参 考 文 献}

1) Burke, T.W.: Perineal reconstrution using single gracilis myocutaneous flaps. Gynecol. Oncol., 57 : 221-225, 1995.

2) Davison, P.M.: A new approach to reconstruction following vulval exicision. Br. J. Obstet. Gynecol., $103:$ 475-477, 1996.

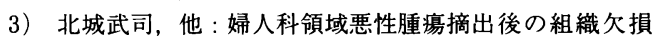
に応用した有茎薄笳皮弁の検討. 整形外科と災害外科。 43(2) : 659-662, 1994.
4) Mathes, S. J., Nahai, F.: Clinical applications for muscle and musculocutaneous flaps. pp.116-117. Edited by C. V. Mosby, St. Louis, 1982.

5）中西秀樹, 他 : 外陰癌の治療経験. 形成外科, 34(2)： 157-163, 1991

6）大西 清, 他 : 会陰部広範囲欠損の再建. 形成外科, 39(4) : 337-344, 1996.

7) Rosen, J.M.: Experience with the island inferior gluteal thigh flap compared with other local flaps for the reconstruction of the pelvic area. Ann Plast Surg., 24 : 498-509, 1990.

8) Soper, J. T.: Long and short gracils myocutaneous flaps for vulvovaginal reconstruction after radical pelvic surgery. Gynecol. Oncol., $56: 271-275,1995$.

9) Stevenson, T.R.: Squamous cell carcinoma of the perineum. Ann Plast Surg., 18 : 248-251, 1987. 